\title{
Tonggo and Martonggotonggo in the Traditional Ceremony of the Toba Batak Community
}

\section{Yessy Octavianna, Robert Sibarani, Hamzon Situmorang, and Nam Syahot Hasibuan}

Student of Doctoral, Post-Graduate Department in Linguistics, Faculty of Cultural Science, University of Sumatera Utara, Indonesia

\section{Abstract}

Every ritual in Toba Batak community uses language as a basic tool in its implementation. The verbal forms used in rituals are usually in the form of incantations (tabas) and prayers (tonggo); tabas is spoken by a shaman while tonggo is spoken by partonggo (the leader of a prayer). Tonggo is spoken with the rhythm of the language according to bound speech; its contents are only in the form of requests, praise, confession, and submission to spirits and it is carried out by serving large and small offerings.

Corresponding Author: Yessy Octavianna ipmi_64@yahoo.com

Received: 1 July 2019

Accepted: 18 July 2019

Published: 31 July 2019

Publishing services provided by Knowledge E

(c) Yessy Octavianna et al. This article is distributed under the terms of the Creative Commons

Attribution License, which

permits unrestricted use and

redistribution provided that the

original author and source are credited.

Selection and Peer-review under the responsibility of the AICLL 2019 Conference Committee. The martonggo tradition consists of prayers in each religious event, customs and other events, which can provide comfort and kindness in an event or party. The purpose of this paper is to describe (1) the meanings of tonggotonggo in the traditional ceremony of the Toba Batak community and (2) the functions of the martonggo-tonggo tradition in the traditional ceremony of the Toba Batak community. This paper uses an anthropolinguistic approach with the analytic parameters of interconnection, valuability, and sustainability. A qualitative paradigm of ethnography is also used in this study by applying twelve steps in observation and interview methods. The function of the tradition of martonggotonggo for the owner's community is as the educational tool, as the projection system and as the means of validating culture. The incantation of Tonggotonggo means that humans expect to be able to obtain prosperity in their lives.

Keywords: Tonggotonggo, Martonggo-Tonggo, Antropolinguistic

\section{Introduction}

Language is a social and cultural product. Language is also an inseparable part of a culture. As a social and cultural product, language becomes a forum for social aspirations, community activities, behaviors, and cultural disclosures including technology created by the community using that language. Language and culture have a direct relationship that can be seen in the presence of speech in cultural events. One of the cultural events which reveals the positioning of language as an important aspect is a ritual event. 
The use of ritual language is unique and different from everyday language. Ritual language is considered a sacred language, or at least as the most powerful medium for communicating with the most holy. Every ritual in the Toba Batak community uses a language as a basic tool in its implementation. The verbal forms used in rituals are usually in the form of spells (tabas), and incantation (tonggo); spells (tabas) are spoken by a shaman while incantations (tonggo) are spoken by parhata (the leader of tonggo).

Tonggo is a prayer spoken with the rhythm of the language according to bound speech, whose contents are only in the form of requests, praise, confession, and submission to the spirit and carried out by serving large and small offerings (Sangti, 1977: 270). Those called in the prayer are the transcendent gods, ancestral spirits, and natural spirits. Prayer is words that have the power to please the transcendent heart.

One of the most important rites in Toba Batak society is the rite of martonggo (incantation), through either giving offerings or not giving offerings. In each, the incantation of tonggo has a basic norm (social norm) of Toba Batak people both individually and in groups. The basic norm is the dependency relationship and partner (supernatural beings), debata (gods); humans with humans because there is clan relationship including ancestors or humans with nature. The society of Toba Batak conveys the incantation of tonggo by giving offerings both in the forms of large or small servings to gods to obtain blessings (pasupasu) and avoid disasters. All blessings that they obtain manifest in livestock breeding (sinur napinahan), abundant yields (gabe naniula), and prosperous society. Basically, the core rite of martonggo and the purpose of Toba Batak offerings are for obtaining the blessings from gods which is synonymous with their life. Thus, in Toba Batak's incantation, Toba Batak people communicate with Ompu Mulajadi Nabolon (the name of Toba Batak gods), and also with the natural spirits through good and beautiful words or sentences because they believe that hat the good and beautiful words or sentences having power or strength to give life (hata na denggan).

The use of tonggotonggo in modern society is now becoming obsolete. In fact, the tradition of Toba Batak society has not passed it down to the next generations, although it holds wisdom and values that need exploration. When the community has begun to abandon the tradition, it is not denied that in fact, the community has abandoned values that it has adopted for generations. In the activities of traditional marriage ceremonies, for example, there is the narration of tonggotonggo which is the attempt to invoke blessings and protection to those who have power beyond human authority to the bride and her household life. This shows the awareness of humans that they have limitations and have the ability to undertake the effort to pray to those who control human life. 
Nowadays, the tradition of martonggotonggo is almost not performed anymore in all rituals of Toba Batak community especially urban areas, and the phenomenon in this community is that the narrative of tonggotonggo is performed during religious and traditional ceremonies of the Toba Batak community. This study discusses tonggotonggo and the tradition of martonggotonggo in the traditional ceremony of the Toba Batak community.

The illustration above gives a way to explore and describe the meanings of the incantation of tonggo in the traditional ceremony of Toba Batak community and the function of the tradition of martonggo in the traditional ceremony of Toba Batak community in Samosir, North Sumatera Province. This article attempts to answer two basic questions, namely 1) What is the meaning of tonggo in the traditional ceremony of Toba Batak community? 2) What are the functions of martonggo in the traditional ceremony of Toba Batak community?

\section{Literature Review}

\subsection{Tonggo-Tonggo}

Tonggotonggo is a prayer arranged poetically and spoken during festive times, full of alliteration, parallelism and so on which is considered poetic or beautiful language. It contains prayer requests to spirits who are trusted by giving large and small offerings.

Tonggotonggo can only be spoken in a traditional and religious ceremony, where it is open to the public (usually in a Batak house (parsantian) or in the yard of the host concerned). It must be pronounced in a bright, wavy, clear, vibrant voice, smooth and concise with parable words. The person who justifies in uttering it is a king, chairman or teacher, shaman who is not born physically and mentally according to the Dalihan na Tolu community concerned. Uttered by them, it is believed to bring blessings (pasupasu) to those prayed for. However, in a traditional concept of the Toba Batak, the giver of blessing (pasu-pasu) is not only carried out by the king, chairman, teacher or shaman but also by their hula-hula (the party who gave the woman) and their uncle (tulang) to boru (the party who accepts women). In other words, Boru must understand the position of hula-hula and tulang and boru must carry out their duties and roles as boru to hula-hula and tulang in the context of custom. So, Boru must respect to their hula-hula and tulang because they are considered to be the blessing givers.

The Toba Batak community has several incantations of tonggo, such as the incantation of tonggo Sianjurmulana, the incantation of tonggo siboru deak parujar and 
the incantation of tonggo sipitu gondang. The incantation of Tonggo sianjurmulana is referred to as devotions and liturgy of community and spiritual worship. This tonggo describes the origins of the development of the Siraja Batak clan community in Sianjurmulana, including the origins of the strictness of the empire and the Constitution (Patik and Uhum), devotions and beliefs (religion).

However, since the influx of foreign influences and the spread of religion to the Toba Batak community, the rite of tonggo-tonggo (incantation) is no longer used anymore in religious rituals but used in the Toba Batak ritual ceremonies. The Toba Batak people have customs inherited from their ancestors and passed down through the oral tradition.

\subsection{Martonggo-Tonggo}

Since long ago, the ancestors of the Batak people have had the tradition of martonggo (praying) in every start and end of religious, customary and other events, which can provide convenience and kindness in an event or party. The delivery of tonggo (prayer) is devoted to the ruler of banua ginjang (upper world), occupied by the ompu mula jadi nabolon (gods) and all his devices are in the form of spirits.

The tradition of martonggo-tonggo is not only found in the Toba Batak people, but also in the Pakpak-Dairi community. The Pakpak-Dairi community knows the term of martonggo-tonggo as mangmang which refers specifically to rituals of chicken that are performed to predict the future events.

The tradition of martonggo-tonggo is usually performed during the religious and traditional ceremonies of the Toba Batak people. In religious ceremonies, the tradition of martonggo-tonggo is commonly used by the Parmalim Batak religion, for example in the tradition of Sipaha Lima and Sipaha Sada, while in the traditional ceremonies, this tradition is used both in traditional of marriage and funeral ceremonies. The ceremony of Sipaha Sada was held to commemorate the birth of gods Simarimbulubosi who had lived a bitter life and pain to atone for the sins of humanity so that they were given a new life by Debata Mulajadi Na Bolon (gods). The ceremony of Sipaha Lima was held to give thanks for the harvest that obtained by humans to be presented as offerings to give more abundant results in the following harvest season. All humans' requests are submitted in all rituals and they are always delivered to Debata Mulajadi Nabolon and his all devices through tonggotonggo.

In the traditional wedding ceremony, this tradition is held after the pamasumasuon (blessing) event of a religious event. This tradition is carried out when the event of marpaniaran (dancing the son-in-law) takes place in front of the guests. Meanwhile, in 
the funeral ceremony, this tradition is carried out during the traditional of sari matua and saur matua ceremonies.

\subsection{Anthropolinguistics}

Anthropolinguistics is the study of humans and culture as a whole. Whereas humans are the creators of culture, on the other hand, culture 'creates' human beings according to their environment. Thus, a very close reciprocal relationship exists between humans and culture.

In culture, the language occupies a unique and respectful place. Besides as the element of culture, the language also has functioned as the most important means of inheritance, development, and dissemination of culture. The relationship between language and culture are very close. The language is part of the culture. These things affect each other, fill each other, and run side by side.

Anthropolinguistics is not only to study the varieties of language but also study the varieties of languages spoken in certain communities. In other words, anthropolinguistics begins with the assumption that mind or language varieties require a speech community.

Anthropolinguistics is often also called ethnolinguistics which examines the structure of language and its functions and it uses in the context of socio-cultural situations. Antropolinguistic studies the structure and relationship of kinship through the kinship terms, the concept of color, the pattern of parenting, or examines how community members communicate with each other in certain situations such as the traditional ceremonies associated with the concept of culture. Through the anthropolinguistic approach it can be understood what people do with language and speech produced, silence and gesture that associated with the context of its appearance (see Duranti, 2001: 1).

Foley (1997: 3) says that Linguistics Anthropology is a branch of linguistics that is related to the position of language in a broader social and cultural context, which has the role of supporting language in combining and sustaining cultural practices and social structures. This concept views the language as having a connection with the socio-cultural and language context as the process of cultural practices and social structures. Foley also explained that this concept views the language as a prism or the core of a cultural concept that seeks to find the meaning behind use, misuse and the use of language in the form of registers and different styles. In other words, this 
science interprets the language to find cultural understanding, and search for language meaning.

In studying a language, culture and other aspects of people's lives, the attention of anthropolinguistics is emphasized on three important focuses, namely 1) performance, 2) indexicality, 3) participation (Duranti 1997: 14). Through the concept of performance, the language is understood as the process of activities, actions and communicative performances, which requires creativity. The language as a lingual element that stores the cultural resources cannot be understood separately from the performance or language activities. The concept of indexicality distinguishes the three types of marks namely index, symbol, and icon. An index is a sign that indicates that there is a natural and existential relationship between the marking and the marked. The concept of participation views language as a social activity involving speakers and listeners as social actors.

In studying the use of language, anthropolinguistics applies three parameters, namely 1) interconnection, 2) valuability, and 3) continuity. The parameter of connection might be a linear vertical relationship or a horizontal formal relationship. The formal relationship relates to the structure of language or the context of a text (the situation, culture, social, ideology) and co-text (paralinguistic, motion-signals, material elements) that are related to language and language processes, while linear relations are related to the structure of the plot like performance. The valuability shows the meanings or functions until the values or norms, and finally comes to the local wisdom of the aspects studied. The sustainability shows the state of the object under study including its cultural value and inheritance to the next generation (Sibarani, 2014: 319).

\section{Research Method}

This research was held by using a qualitative paradigm with the ethnographic model by applying twelve steps in observation and interview methods. The collecting data in this research apply the observation and interview methods as indicated by the qualitative paradigm of ethnographic models applicable by Spradley. The observation method conducted is the direct and participatory observation.

The methods of interview data collection were conducted with ethnographic record techniques, descriptive questions, structural questions, and contrast questions, while 
the observational data collection was conducted with the descriptive observation techniques, focused observations and selected observations. In accordance with a qualitative paradigm of the ethnographic model, the analysis of data collected from the in depth, open-ended interview was conducted with the ethnographic interview technique analysis, domain analysis, taxonomic analysis, and component analysis. The continuation of data analysis was conducted by discovering and taking cultural themes as a result of interpretation to describe the conclusions of meaning and functions of tonggo and martonggo in the traditional ceremony of Toba Batak community.

\section{Result and Discussion}

\subsection{The meaning of Tonggotonggo in the Toba Batak traditional ceremony}

The word of tonggo comes from the Batak language which means 'prayer', tonggotonggo means 'prayers', martonggo means 'praying' while martonggotonggo means 'pray-prayer', where the prayer offered by partonggo (the prayer leader) is more than one type of prayer. However, the incantation of tonggo can also mean 'calling'. They called the transcendent in their prayer, namely gods, ancestral spirits, and natural spirits. The prayer is words that have the power to please the transcendent heart.

The incantation of tonggotonggo is the utterances or sequences in prayers that are delivered to gods (Debata Mulajadi Nabolon) and all his envoys that have glory and power (marsahala). It is delivered based on each dignity of gods (tohonan). It is offered to gods (Ompu Debata Mulajadi Nabolon) who created the heavens, earth, and all its contents, and also offered to all his envoys. It is also pronounced in various rituals, namely the ritual of mararisabtu, the ritual of martutuaek, the ritual of pasahat tondi, the ritual of mardebata, the ritual of mangan napaet, the ritual of sipaha sada, and the ritual of sipaha lima, including in ritual of traditional ceremonies of marriage and funeral. It is also used when asking for the gondang (the names of traditional musical instrument) to pargonsi (music players).

The meaning is the intent contained in each text of tonggotonggo. In each text of tonggo that spoken contains a human request to obtain the life welfare. Their expectancy conveyed as a prayer request to gods. The prayer offered to gods is earnest prayer and is done in a certain way. The incantation of tonggo is a form of communication in the ritual of martonggo, so humans must be in a holy state, both holy 
physically and spiritually. The spiritually holy is obtained by asking for forgiveness to gods (Debata) for the sins committed by humans.

The essence of tonggotonggo in each ceremony, both in religious and traditional ceremonies is as important as offerings which also become an integral part of the two ceremonies. If the ceremony is performed without it, the ceremony is deemed illegitimate and it has no meaning. The incantation of tonggotonggo is likened to a vehicle or tool, in delivering offerings as well as voicing desires and wishes.

In the traditional life of the Toba Batak people, especially Parmalim Batak religion, tonggotonggo is delivered through the seven rules of Parmalim's ritual. It consists of sacred words which are delivered to gods (Debata Mulajadi Nabolon) and all the envoys (sahala marsangap sahala martua). In the process of delivering tonggotonggo these offerings (pelean) are in accordance with the rituals performing. In some rituals, it is delivered with the accompaniment of a traditional musical instrument that is gondang as a medium for delivering prayers to the creator, namely gondang sabangunan, while in other rituals it is not sounded it.

Tonggotonggo is the gratitude for what humans have received in their lives, asking for protection and salvation, obtaining the eternal life, and begging for forgiveness for all sins and actions that infringe gods commands and prohibitions.

Tonggotonggo has various roles in human daily life, namely as a guideline for behaving as well as social control. It is delivered to gods (Debata Mulajadi Nabolon) and all his envoys which is something highly believed and sacred. They do this to achieve the same goal, namely to obtain the life of the human soul (hangoluan ni tondi) or the firmness of faith.

Tonggotonggo is able to provide the new spirit and strength in a person's life. Likewise, when the ritual is done completely, the faces of the ritual followers look sparkling like a sign of the calmness of the heart and soul felt after doing the ritual of martonggo. Tonggotonggo is able to change one's soul to be more calm and peaceful. Nevertheless, the ritual followers realize that all requests which are submitted to gods (Debata) must be accompanied by undertakings that refer to regulations of gods.

\subsection{The function of the tradition of martonggotonggo in traditional ceremony of Toba Batak}

In general, the contents of martonggotonggo focus on three things, namely 1) expressing gratitude for the blessings and bounty given by God such as health (hahorasan), sustenance and it can perform in religious ceremonies, 2) sounding related to offerings 
that are already available and at the same time begging to accept them, and 3) asking for forgiveness of sins, and begging to always plead for health (hahorason), easy sustenance, glory (hasangapon), hatuaon (happiness) both in this world and later after humans die.

When performing the ritual of martonggo, the leader of tonggo will invoke for forgiveness to gods (Debata Mulajadi Nabolon). Everything that is expected by the human conveys through the rite of tonggotonggo solemnity. When performing the ritual of martonggo, the leader of tonggo hopes that all the participants will follow each type of tonggotonggo what they say. All the participants must respect the atmosphere of martonggo, and pray heartfeltly and sincerely so that the tonggotonggo that is delivered can be granted. When the ritual is done, the leader of tonggo is very hopeful and undertaking so he can deliver the rite of tonggotonggo. By leading the ritual, the leader of tonggo will feel great tranquility and very extraordinary beliefs; because when performing the ritual, he feels that he is talking to gods (Debata Mulajadi Nabolon).

When the leader of tonggo cannot attend the ritual, he will feel like there is less in his life. If he does not take part in the ritual, it means not participating in performing the tradition of martonggo so that there is something has not conveyed through the tonggotonggo that he usually conveys. This tradition (martonggo) is the medium of expressing the expectancy, prayer, and desire in the form of words delivered solemnly. This tradition provides new hope and enlightenment for those who carry out their feelings, happy, relieved and increasingly excited after performing this tradition (martonggo).

The tradition of martonggotonggo certainly has a function for its owner. The functions of martonggo are as follows:

1) As the educational tool,

In the tradition of martonggo there is a description of the relationship between humans and the gods and the relationship between humans and other creatures including the relationship with their environment. Praying means humans talk to gods (supernatural beings). In communicating with the gods, humans use human language and human social relations. The relationship between humans and the gods shows the relationship between servants and gods. In using the language in tonggo, the leader of tonggo (partonggo) must use the good and beautiful words and there should be no mistakes when conveying a prayer. If the tonggo which is delivered incorrectly and not smoothly this will make it become worthless. For this reason, it is necessary for the selected person deliver the tonggo in accordance with the Dalihan Na Tolu community provisions, good facilities and suitable situations in delivering prayers. 
2) As the projection system,

In the tradition of Martonggo, there is a description of the relationship between human dependence and gods. Humans depend on the gods who create the world and regulate human life. This tradition is usually held at the religious and traditional wedding and funeral ceremonies. In carrying out the ceremony, usually by giving offerings or servings to the gods and sacrifices something such as a buffalo or ox by hitting a set of the traditional musical instrument or what is called gondang sabangunan. The purpose of giving offerings is to ask blessings for the gods, ask for guidance and protection, ask to be given health and be kept away from reinforcements. The Toba Batak community (Dalihan na Toba Batu Tolu community) believes that everything they ask will be granted by the gods through the incantation of tonggo that they convey and they give the offerings to the gods.

3) As the cultural certifier,

In the tradition of martonggo, both in religion, marriage and funeral ceremonies, there are texts that characterize the old beliefs adopted by the previous community until now. Both cultures are acculturated in forming a harmonious culture between the two and the community justifies the culture.

\section{Conclusion}

Based on the description in the discussion above, it can be concluded that the incantation of tonggotonggo in the traditional ceremony of the Toba Batak community has a meaning that signifies a purpose. The meaning is the purpose contained in each text of tonggotonggo. In each text of tonggo that is spoken there is a human request to get life welfare. The hope was conveyed as a request in prayer to the gods (Debata). The prayer offered to the gods (Debata) is earnest prayer and is done in a certain way. The incantation of Tonggotonggo as the gratitude for what humans have received in their lives, to asking for protection and salvation, to obtaining the eternal life, and to begging for forgiveness for all sins and actions that violate gods commands and prohibitions.

The function of the tradition of martonggotonggo for the owner's community is as the educational tool, as the projection system and as the means of validating culture. The incantation of Tonggotonggo means that humans expect to be able to obtain prosperity in their lives. 


\section{Acknowledgment}

This article was financially supported by LPDP. I would like to thank it.

\section{References}

[1] Duranti, Alessandro. 1997. Linguistic Anthropology. New York: Cambridge University Press.

[2] Duranti, Alessandro. 2001. Linguistic Anthropology: A Reader. Massachussets: Blackwell Publishers.

[3] Duranti, Alessandro. 2003. Language as Culture in U.S Anthropology: Three Paradigms. Current Anthropology Volume 44, Number 3, June 2003. The WennerGren Foundation for Anthropology Research.

[4] Duranti, Alessandro. 2012. Anthropology and Linguistics. Sage Book Fardon Journal. Volume. 1, Number. 1. Indd. Hal 12-23

[5] Foley, William A. 1997. Anthropological Linguistics: An Introduction. Oxford: Blackwell.

[6] Sianipar, Sutan Badiaraja. 1977. Sejarah Batak. Karl Sianipar Company. Balige. Sumatera Utara.

[7] Sibarani, Robert. 2004. Antropolinguistik: Antropologi Linguistik atau Linguistik Antropologi. Medan: Penerbit Poda.

[8] Sibarani, Robert. 2017. Batak Toba Society's Local Wisdom of Mutual Cooperation in Toba Lake Area: a Linguistic Anthropology Study. International Journal of Human Right in Healthcare. Vol 11 No. 12. Hal. 40-55.

[9] Sibarani, Robert. 2018a. The Role of Local Wisdom in Developing Friendly City. in IOP Conference Series: Earth and Enviromental Science 126. Conference 1. IOP Publishing.

[10] Sibarani, Robert. 2018b. Concerning Toba Batak's Local Wisdoms and Cultural Values for Regional Character Building. Indiana Journal of Science and Technology. Vol. 11 (20), DOI: 10.17485/ijst/2018/v11i20/114298, May 2018.

[11] Sitanggang, JP. 2014. Batak Na Marserak. Pustaka Sinar Harapan. Jakarta.

[12] Spradley, James P. 1979. The Ethnographic Interview. Harcourt Brace Jovanovich College Publishers. United States of America.

[13] Spradley, James P. 1980. Participant Observation. Holt, Rinehart and Winston. United States of America. 